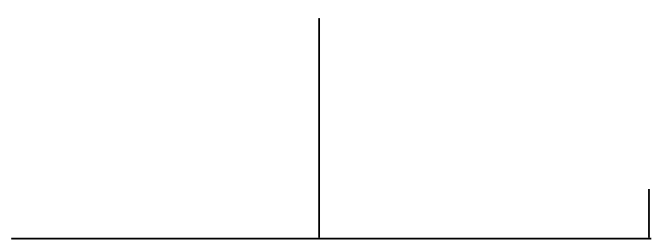

Rev. Latinoam. Psicopat. Fund., São Paulo, v. 13, n. 2, p. 333-351, junho 2010

\title{
Paranoia (Verrücktheit) - 1904 ${ }^{*}$
}

Emil Kraepelin

Aqui publicamos a tradução brasileira (1905) do capítulo sobre a paranoia, extraído da sétima edição alemã (1904) do tratado (Lehrbuch) de psiquiatria de Emil Kraepelin. O autor discute o diagnóstico da paranoia e, particularmente, faz a distinção entre a paranoia e a demência precoce.

Palavras-chave: Emil Kraepelin, paranoia - história, demência precoce história

1. Traduzido da obra do Prof. Emil Kraepelin, Die Psychiatrie, vol. II, p. 590. Leipzig, 1904. Evito qualquer apuro do estilo para não me afastar da letra original. (Nota do tradutor Antonio Austregésilo).

* Transcrito de Arquivos Brasileiros de Psiquiatria, Neurologia e Ciências Afins, Rio de Janeiro, vol. 1, n. 1, p. 98-106; vol. 1, n. 2, p. 183-196; vol. 1, n. 3-4, p. 301-309. 1905. Como indica A. Austregésilo na nota acima, sua tradução é literal; além disso, parece não ter havido revisão do português, pois muitas frases têm sintaxe incomum e erros de pontuação, sendo frequentes as separações entre sujeito e verbo, etc. Optou-se por fazer a atualização ortográfica e manter a pontuação e a peculiar sintaxe original, exceto em casos de evidentes erros tipográficos. As duas notas de Austregésilo em alemão foram reproduzidas com pequenas correções ortográficas. Revisão técnica de Ana Maria G. R. Oda. 


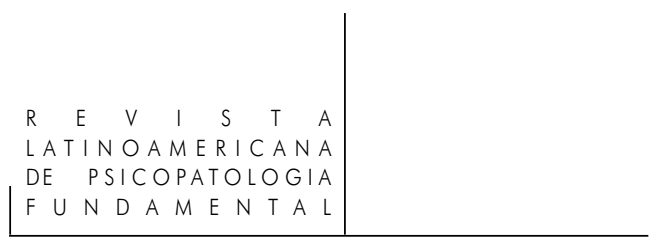

Sob o nome de paranoia reúne uma grande parte dos psiquiatras alemães todas as moléstias mentais funcionais nas quais se desenvolve uma perturbação principal ou exclusiva no domínio da atividade da inteligência.

Como característica essencial desta moléstia é considerada simplesmente como de valor a aparição de concepções delirantes e alucinações (Wahnidee und Sinnestäuschungen).

A mais profunda razão para esta tão confusa compreensão está na história do desenvolvimento da mesma.

Segundo o antigo ensinamento de Griesinger, era sempre a paranoia o resultado de uma precedente loucura afetiva.

Somente os estudos de Snell, Westphall, Sander, em primeiro lugar, se dirigiram, de modo que foi por todos eles reconhecida uma forma primária de paranoia.

Debaixo da impressão deste iniludível progresso, tornou-se necessário contrapor, a esta nova forma de moléstia primária da inteligência, a mania e a melancolia, nas quais as perturbações são da esfera do sentimento.

As perturbações psíquicas semelhantes ao quadro clínico da paranoia, mas que eram consecutivas às perturbações afetivas ora tristes, ora exaltadas, acompanhadas de ilusões e alucinações - isto é, que se sucediam à mania e à lipemania - foram denominadas de paranoia secundária.

Para a diagnose era, pois, de maior significação saber se em cada caso havia perturbações do sentimento (Stimumng) ou da inteligência como ponto de partida para a aparição da moléstia.

Particularmente foi perturbador para o posterior desenvolvimento da psiquiatria clínica o ter Westphall, que deu grande impulso à psiquiatria, admitido, [tendo sido] o primeiro, um decurso agudo da paranoia, terminado pela cura.

As últimas conclusões destes ensinamentos têm nos mais modernos tempos o apoio de Cramer e Ziehen.

Pela deslocação da concepção primitiva, que contava somente os casos crônicos e incuráveis, tornou-se extraordinariamente amplo o quadro clínico da paranoia.

Rev. Latinoam. Psicopat. Fund., São Paulo, v. 13, n. 2, p. 333-351, junho 2010 
Quando o decurso e o ponto de partida da moléstia não mais eram acentuados, ficavam, então, as perturbações psíquicas: o aparecimento da concepção delirante e perturbações sensoriais como os únicos elementos demonstrativos da paranoia.

Necessariamente deviam ser incluídos, então, uma grande série de tipos no mesmo quadro clínico da paranoia, tipos que, clinicamente tomados, se afastavam completamente e que nada tinham em comum com ela, como a amência, a loucura alcoólica e inúmeros casos pertencentes à demência precoce e à loucura maníaco-depressiva.

Falou-se então ingenuamente de uma paranoia periódica!

Não necessitaria quase dizer que considero este desenvolvimento da questão da paranoia completamente falho.

Neste se nos apresenta palpavelmente o erro capital da nossa psiquiatria clínica nos últimos decênios; formando como limites do quadro clínico o que é exclusivamente sintomático, baseados sobre hipóteses infelizes. O que estava estabelecido basicamente como oposição entre a alteração da inteligência e do sentimento é apenas um fato psicológico mas nunca clínico. Nos verdadeiros tipos clínicos vemos ambos os fatos misturarem-se de uma maneira incalculável, isto é, as alterações do sentimento e da inteligência.

A quem isto não esclareça, procure então agrupar, entre os reconhecidos quadros clínicos da paralisia geral, os casos segundo a formação primária ou secundária das concepções delirantes (Wahnidee).

Por este claro exemplo, do qual a concepção clínica das alterações psíquicas ainda nada pode adiantar, torna-se até enfadonho repetir que as concepções delirantes e as perturbações sensoriais de per si não servem para determinação de um tipo mórbido, e isto é tão acidental e de somenos importância como o aparecimento do mau humor ou da excitação em vários doentes.

Pode-se bem verificar isto, quer na loucura maníaco-depressiva quer na demência precoce, se não se tiver de antemão os olhos tapados com ideias preconcebidas.

Na realidade, qualquer tentativa no sentido de coordenar o grupo das paranoias e separá-lo de outras formas de loucura terminou sempre com a confissão que as formas mistas, as formas de transição sobrepujam excessivamente as próprias formas e conduzem até, segundo se disse, a transpor completamente o limite de outras formas de loucura afetiva, basicamente diferentes.

Por isso não subsiste o único alicerce da atual compreensão da paranoia, isto é, a artificial oposição entre moléstias do pensamento e do sentimento (Verstandes und Gemüthskrankheiten).

Não duvidamos que a desesperança posta neste caminho em busca de uma certeza nos mostrará, em grande parte, a culpa na geral falta de vontade para os misteres da clínica psiquiátrica. 
Em que nos será útil talvez analisar o quadro clínico das grandes afecções mentais na sua mais sutil feição, quando não sabemos ao certo se o doente está são, se ele é periódico, se apenas débil mental ou se se tornará louco na velha acepção da palavra (verrü̈kt)?

Sobre estas importantes questões, deve-nos o diagnóstico dar qualquer explicação que nos satisfaça e nos esclareça o espírito. Para nós de nada adianta nessa orientação dada pelos psiquiatras à paranoia como moléstia universal, que abraça para muitos especialistas de 70 a $80 \%$ do material todo dos manicômios.

Sabemos que as concepções delirantes e as alterações sensoriais (ilusões ou alucinações) podem sobrevir nas várias formas de alienação, satisfatórias ou não, agudas ou crônicas, simples ou periódicas; por este simples fato não temos o direito de tirar nenhuma conclusão sobre o desenlace do caso.

Diante disso não há meios que nos esclareçam verdadeiramente sobre as condições próprias e importantes das moléstias mentais senão fixarmos a atenção no decurso da moléstia e no seu desfecho final.

Foi adquirido, como é sabido, o conhecimento da paralisia geral e seus sinais somáticos; ora, pela experiência clínica sabemos que todo indivíduo que apresentar perturbações da palavra e paralisia, de acordo com o quadro clínico da moléstia, deve perecer. Quando tivermos diante de nós um grupo de casos de êxito semelhante, poderemos incluí-los na mesma rubrica clínica, como sucede com a demência precoce.

Tais são as considerações, de passagem, que me obrigam a tomar um lugar desviado, mas com fundamento, na concepção da paranoia.

Só posso considerar tais casos clínicos quando são conduzidos para o mesmo desfecho, abstraindo casos intermediários e diferenças incidentes. Não se pense com isto que casos geralmente curáveis ou incuráveis, de período agudo ou crônico necessitem por força pertencer a diferentes moléstias. Na realidade, é preciso que se examine com cuidado essas diferenças que, indiscutivelmente, são muito mais importantes do que os sinais sintomáticos que são comuns, e se verifique se realmente existem decursos de moléstias iguais ou somente iguais na aparência.

Eu considero por isso naturalmente a criação de uma paranoia aguda como uma quimera, porque o caráter essencial da moléstia - a paranoia - é a incurabilidade e a persistência da concepção delirante; ora, na paranoia aguda estes caracteres desaparecem.

Sendo a paranoia uma moléstia, deveria ser aguda ou crônica. Destaco somente esta última forma porque sei prognosticar com acerto, e não a chamada forma aguda. Entretanto, grande número de casos crônicos do que se continua a chamar de paranoia pertencem, creio eu, àquelas formas clínicas em que as concepções delirantes aparecem com fraqueza intelectual evidente, isto é, como 
a demência. Vemos nestes estados concepções delirantes, contraditórias, eróticas, terríficas, de mil modos variáveis, dissipando-se em curto ou longo tempo.

Ora, estes quadros clínicos trazem claramente os delineamentos da demência hebefrênica, catatônica ou senil.

Ninguém negará que uma e a mesma moléstia, conforme talvez sua violência ou a capacidade de resistência do paciente, pode hoje curar e amanhã cair em demência. Se o desfecho for favorável, devemos aproximar todas essas formas umas das outras, porque apresentam as mesmas perturbações fundamentais, e que em aparência exibem um cunho diferente.

Como ordinariamente a anatomia patológica nos deixe em completa dúvida sobre as diferenças íntimas, não vejo outra possibilidade de demonstrar a semelhança do quadro clínico senão pela profunda perturbação mental em que os doentes caem (demência).

Que uma moléstia de por si possa apresentar formas de decursos agudos ou crônicos mostram-nos a paralisia geral, a demência precoce, e de certa forma também a loucura maníaco-depressiva. Sempre são, porém, os incidentes agudos parte de um decurso crônico fundamental, ficando a prognose para o estado final sempre a mesma.

Justamente este caráter não pertence à chamada paranoia aguda. A joeiração ou o apuro dos casos de moléstias correspondendo ao tipo da chamada paranoia aguda vai demonstrando indiscutivelmente, de ano para ano, que se havia juntado no mesmo quadro clínico moléstias diferentes.

Por outro lado, a forma clínica da loucura que até hoje ninguém soube negar pertencer à verdadeira paranoia - a dos querulantes - que é de decurso essencialmente crônico, nada tem de comum absolutamente nem de semelhante com a chamada paranoia aguda. O fato de aparecer uma concepção delirante (Wahnbildung) é de um desvalor clínico que em toda parte aparece. Ninguém pode negar este fato com seriedade.

Por todas estas razões eu considero a paranoia aguda um absurdo, pois ela não apresenta uma causa própria, um desfecho, sinais clínicos que justifiquem a sua inclusão no tipo mórbido da paranoia. Se se quisesse, em todo caso, conservar o quadro clínico desta moléstia, não se devia chamá-la de paranoia, porque lhe faltam caracteres fundamentais como a incurabilidade, a persistente concepção delirante.

Por outro lado, porém, grande número de casos de decurso crônico que se costuma reunir à paranoia necessita, segundo creio, de uma observação especial, porque sempre o quadro delirante (Wahnbildung) anda de parelha com o enfraquecimento mental. Vemos nestes casos que as manifestações delirantes aceitam rapidamente formas muito extravagantes, contraditórias; tornam-se ora muito opulentas, ora moderadas; modificam-se muitas vezes, desaparecendo finalmen- 
te em um prazo mais ou menos longo. Ora, estes quadros clínicos pertencem na maioria à loucura catatônica, hebefrênica ou senil. Nestes casos referidos, como também nos alcoólicos e epilépticos que eu excluo da paranoia, se bem que muitos autores adotem uma paranoia alcoólica, epiléptica, o sistema delirante (Wahnbildung) é constituído por perturbações mentais fundamentalmente de outra espécie. Aí o delírio é medíocre e um sinal muito secundário da geral representação da moléstia. No seu desenvolvimento e na forma ele deixa também, assim como no estado geral da personalidade que o acompanha, conhecer a particularidade mais ou menos clara do processo mórbido, básico e estável.

Por outro lado, existe sem dúvida um grupo de casos nos quais as concepções delirantes (Wahn-vorstellung) se bem que não constituam exclusivamente o quadro clínico são todavia o indício mórbido que mais se sobressai.

Neste grupo costuma-se desenvolver um inabalável sistema delirante lento e duradoiro, com completa conservação do discernimento ou clareza e ordem na associação do pensamento, da vontade e da ação. ${ }^{2}$

São para estas formas que eu pretendo reservar o nome de paranoia. Conduzem necessariamente a uma completa modificação em toda maneira de apreciar a vida, a uma loucura de posição (Verrükung), as quais se apoderam do doente diante das pessoas ou coisas que se acham em torno dele. O desenvolvimento desta moléstia parece executar-se sempre com muita lentidão. O começo que ordinariamente se estende por muitos anos é constituído por pequenas dissonâncias, desconfianças e, provavelmente também, por indeterminados incômodos corporais e medos hipocondríacos. O doente acha-se descontente com a sua própria situação: sente-se abandonado; julga-se talvez tratado sem o mesmo amor pelos seus pais e irmãos; particularmente não o procuram compreender; ninguém procura saber do seu estado d'alma, das suas singularidades. Desenvolve-se assim uma oculta e crescente oposição, de vários modos, entre ele e os circunstantes. Ele está para o seu meio como um homem estranho de um mundo diferente. As revelações para com ele são exteriores, desnaturais, inimigas, mesmo. "Deus é o meu pai e a Igreja minha mãe", dizia um doente que por frequentes jejuns procurava amortecer em si a matéria, para chegar desta maneira a uma íntima relação com Deus. Por isso o paranoico foge de tudo; encontra-se com os outros asperamente, desviando-se; procura a solidão para imperturbavelmente poder seguir os seus pensamentos, entregando-se a leituras inconvenientes e incompreensíveis.

2. Hier pflegt sich ganz langsam ein dauerndes, unerschütterliches Wahnsystem bei vollkommener Erhaltung der Klarheit vie Ordnung in Denken, Wollen und Handeln heraus zu entwickeln. (N. da T.)

Rev. Latinoam. Psicopat. Fund., São Paulo, v. 13, n. 2, p. 333-351, junho 2010 
No íntimo do doente existe um profundo desejo para o que é grande e elevado, um anelo oculto para as ações célebres, uma inabalável esperança para as felicidades imagináveis.

Cada vez mais se arraiga nele a persuasão de que nasceu para algo de especial. Concentra-se ou pensa no seu pendor, na missão que ele tem a exercer no mundo. Todos os insucessos práticos não o desencorajam. Pouco a pouco, as cismas mórbidas começam a influenciar sobre a série de suas ideias e de suas percepções.

Nota que nesta ou naquela ocasião que não é mais tratado com a amabilidade de outrora, que estão diante dele retraídos, que fogem dele e que apesar de muitas demonstrações hipócritas de amizade, como ele julga, contudo não querem mais nada com ele tratar.

Em consequência disso, excita-se a sua susceptibilidade e sua desconfiança; começa uma observação errônea, julgando que o seu gesto casual, o seu olhar surpreendido são sinais ocultos de um íntimo sentimento hostil.

Nas conversas da mesa o doente percebe conciliábulos secretos, e as mudanças de conversa com a sua chegada são feitas com premeditação. Assobiam de modo perceptível determinadas canções, para com isso recordar incidentes de seu passado, para darem sinal de que modo podem agir; nas peças teatrais encontra referências especiais à sua vida e aos seus atos; o padre no púlpito, o tribuno em seus discursos fazem especiais alusões que ele não pode deixar de compreender; encontra repentinamente, continuamente a mesma pessoa que o olha de um modo particular, e que parece segui-lo; casualmente o fixam, olham de soslaio; tossem e escarram ao se aproximarem dele; em lugares públicos afastam-se dele ou quando ele chega se levantam; lançam-lhe olhos furtivos e criticam-no.

Cocheiros, trabalhadores, empregados de estrada de ferro conversam a seu respeito; em toda parte a atenção sobre ele é atraída; seu vestir é imitado por numerosos desconhecidos apesar de ser pouco comum. Algumas frases que deixa escapar vão transformadas em expressões correntes.

Um dos meus doentes tinha tomado o amarelo como a cor do espírito; no dia seguinte usava todo o mundo rosas amarelas, pois que a rosa é o símbolo do silêncio, para lhe indicar que ele fosse prudente e se calasse. "Quem quer contar o que aqui para mim quer dizer!"’3

Todas essas noções são de per si de igual valor; surgem em todos naturalmente, sem nenhuma particularidade, como casuais; o doente, porém, visa tudo mui significativamente "porque tudo foi tratado com especial argúcia"; o doente

3. Wer will all das aufzählen, was hier zu mir spricht! (N. da T.) 
descobre arranjo premeditado naquilo que foi casual, atrás do que ele descobre uma nota oculta de malignidade.

$\mathrm{Na}$ realidade, tudo que se faz neste sentido é executado com muita habilidade para iludi-lo e evitar-lhe qualquer possibilidade de aceitar uma defesa de efeito contra todo sistema de espionagem e observação. Toda vez que ele chama alguém para lhe dar satisfações e dizer que tudo perscruta, porta-se a pessoa como se fosse completamente inocente e inventa toda a espécie de subterfúgio; ela, pessoa, não vai diretamente ao alvo, porém, alcança-o por circunlóquios, mencionando os fins reais somente com uma obscura indicação; vai amavelmente ao encontro dele para iludir sua atenção; enovela-o em conversas curiosas; faz-se-lhe toda espécie de mistificações, com ideias ocultas, cujo verdadeiro sentido ele logo reconhece.

Da curiosa transplantação que se opera no doente em sua relação com o mundo exterior dá talvez uma indicação o seguinte trecho, extraído do livro diário de um doente que se supunha atacado por uma liga secreta para aumento ou progressão da pederastia:

Que uma liga com o fim que se reconhece, tudo procura fazer para que o seu fito não chegue à publicidade, e que sua propaganda é feita por meios ocultos e simbólicos, está claro. Como porém essa liga não tem certeza da influência exercida e da posição sobre o indivíduo, ela procura atrapalhá-lo por meio do correntes, paralelamente, com artifícios para iludi-lo, salvaguardando assim as revelações desagradáveis ao indivíduo a que se dirige. Assim por exemplo, eu tinha outrora, como acontece a quase todo mundo, umas expressões estereotípicas, entre outras, "por certo" e "quase não se acredita"; pois bem, eu encontrei estas duas mesmas expressões, e ainda outra, como título de um reclame, escrito em letras gordas, no indicador geral da liga.

Por este contínuo trabalho de prevenções e de observações obtém o doente a explicação que existe contra ele uma grande conspiração. São espalhadas calúnias sobre ele, dizendo que adquirira moléstias nervosas por desregramento, que é sifilítico e pederasta.

Diz que sua fotografia foi enviada a bordéis para que julguem ser ele frequentador diário dos mesmos, apresentaram contas falsificadas para demonstrar que ele bebia diariamente quantidades absurdas de álcool.

A comida apresenta-se com um gosto altamente duvidoso. O vizinho de mesa adoece, depois de ter bebido casualmente em seu copo. Querem, por força, liquidá-lo, enlouquecê-lo, conduzi-lo a anormalidades sexuais, ao onanismo. Estes fins pertencem, como supõe, a uma sociedade que trabalha por meios espantosos e à qual pertencem não só todas as espécies de pessoas de família, mas também juízes, jornalistas, historiadores, padres e literatos. Muitas vezes suas inimizades são produzidas ou por pessoas determinadas, ou então é uma liga ge- 
ral de maçonaria, socialistas, os quais reunidos por um pacto temeroso e solene procuram invalidar com particular fundamento o valor do paciente.

De parelha com o delírio de perseguição caminham em regra as ideias de grandeza.

Às vezes conservam-se limitadas a um amor próprio exageradamente elevado. Já a monstruosidade, o exagero de forças que o doente possui, são postos contra ele e indicam em excesso o que vale sua própria personalidade, suposta centro de tais esforços.

O paciente julga-se possuidor de habilitações especiais, sendo insigne poeta, músico, pintor, descobridor, sábio; dedica grande atenção ao seu exterior, espera algo de si próprio, crê-se destinado a ocupar no mundo um lugar saliente.

Além disso, porém, depois de muitos anos de sombria meditação aparece frequentemente vitorioso no doente o pressentimento de que ele não é o verdadeiro filho de seus pais, mas descendente muito mais elevado e nobre.

A causa externa desta ideia patológica, que para ele fica logo inabalável, é frequentemente um acidente comum. Numa disputa usa o pai de expressões inacostumadas, violentas, que jamais empregaria a um verdadeiro filho. $\mathrm{O}$ doente percebe que seus pais segredam no quarto vizinho, empalidecem à sua entrada, saudando-o com especial seriedade; em sua presença é citado "significativamente" o nome de alguma personagem altamente colocada; na rua, no teatro, qualquer senhora da alta sociedade, distinta, o olha insistentemente com amabilidade fora do comum; observando o retrato de um conde ou príncipe, do busto de Napoleão, julga-se de repente, espantosamente semelhante às personagens; enfim, chega-lhe às mãos uma carta em cujas entrelinhas, sem grande esforço, lê o grande segredo.

Com especial satisfação reconhece o doente que pelos que o cercam, próximos ou distantes, é reconhecida a superioridade de sua pessoa e sua posição, mais ou menos claramente. É tratado, onde se apresenta, com iniludíveis provas de consideração; pessoas estranhas, diante dele, tiram o chapéu com respeito; a família real procura-o encontrar com a maior frequência possível; a música na parada ou no teatro começa a tocar logo que ele chega.

Nos jornais que o criado lhe traz, nos livros que o livreiro lhe envia encontra alusões, mais ou menos disfarçadas, ao seu destino.

Os transeuntes na rua o acompanham com comentários de aprovação relacionados a si. Não raras vezes consegue ele determinar em certas ocasiões a intervenção direta da previsão nos destinos de sua vida.

Das variações do tempo, do estranho brilho das estrelas, do voo dos pássaros, do traje das pessoas que encontra, do pedaço de papel que acha a caminho do campo, claramente se evidencia que Deus vela de modo especial sobre ele, indicando com sinais o modo pelo qual ele deve agir, e cuja significação logo 


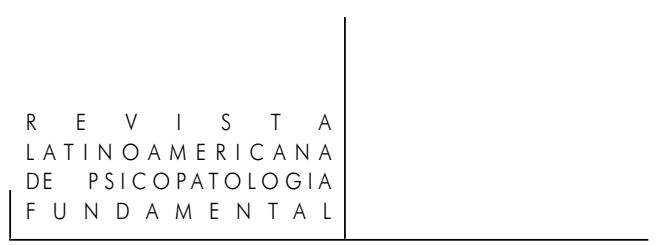

compreende e executa à risca, com alegre confiança. Em consequência de todas essas experiências estabelece-se uma vasta rede de relações cheias de segredo, cujo centro é ocupado pelo doente. É herdeiro do trono, reformador, príncipe da paz, messias, mãe de Deus; obtém seus pensamentos de Deus, torna-se escolhido instrumento do céu.

Em alguns casos faz o doente a observação que a pessoa do sexo oposto, distinta, real ou pretendidamente com uma posição saliente, tem por ele inclinação, dedicando-lhe evidente atenção (paranoia erótica).

Às vezes é um olhar que percebe, um pretenso passeio diante da janela, um encontro casual, que deixa perceber à certeza do doente esse amor oculto a si voltado; mais frequentemente, porém, ele só chega a saber por meio de alusões disfarçadas das pessoas que o rodeiam, pelos jornais, sem que ele talvez jamais tivesse visto o causador do fato.

Muito em breve aumentam os sinais da compreensão secreta. Qualquer acontecimento casual, traje, encontro, leitura, conversa, tudo serve de pretexto para relacionar suas conjecturas. Seu amor é um segredo que está no domínio público e é objeto de atenção geral: em toda parte falavam nesse assunto, se bem que sem expressões claras, sempre, porém, com delicadas alusões, cujo profundo sentido ele bem compreende. Naturalmente esse extraordinário amor por enquanto precisa ser conservado em segredo; por isso é que o doente não recebe todas as notícias diretamente mas sim por intermédio de outrem, pelo jornal, em forma de observação oculta. Da mesma forma sabe ele, por meio de alusões, colocar-se em contato com o objeto de seu amor.

O voo dos pombos que simboliza para ele a amante, mostra-lhe que foi compreendido, que alcançará finalmente, depois de longas lutas, seu alvo.

Qualquer pessoa com a qual entra em contato parece-lhe a eleita que se disfarçou para ocultar ao mundo sua inclinação, mas ele consegue, por um pressentimento secreto, reconhecer o objeto de seus sonhos, debaixo das mais palpáveis dessemelhanças, até da diversidade do sexo!

Este curioso delírio pode prolongar-se durante longo tempo pelo modo descrito, alimentado especialmente por disfarçadas participações de jornais, sem que se avance no modo comum de proceder do paciente, que procura sempre conservar em segredo seu tema, fazendo mesmo alguma coisa de contrário.

No subsequente decurso não raramente se ligam alucinações no sonho, a sensação de um beijo etc.

É aí a coloração do amor sempre fanaticamente romântico, frequentemente platônico, sendo habitualmente desenvolvido de um modo insano o onanismo.

Entre os tempos bem-aventurados intromete-se às vezes profunda contrição, a sensação de sua inferioridade diante do ideal adorado, com indeterminado delírio de pecado.

Rev. Latinoam. Psicopat. Fund., São Paulo, v. 13, n. 2, p. 333-351, junho 2010 
A aparição de todas essas formações de delírio executa-se principalmente pela interpretação mórbida de reais acontecimentos. Às vezes são percepções reais erroneamente interpretadas. Observações de todo indiferentes tomam para o doente uma face secreta atingindo à sua própria pessoa.

Uma nódoa, por exemplo, na roupa, um furo na botina, não são consequências do desgosto comum, mas uma realidade que atrai a atenção, cuja explicação depende das circunstâncias especiais dos atos inimigos.

Sensação de vertigem, zumbido do ouvido, calor na cabeça, crises intestinais indiscutivelmente para ele tentativas de envenenamento: "Já sei que isso é!" Especialmente rica é essa fonte na conversa dos que o rodeiam e no assunto da leitura. Sempre é usada a linguagem por metáforas: "O senhor supôs que eu não o compreendia".

Frequentemente são consideradas uniões íntimas entre dois acontecimentos casuais subsequentes. Um doente apresentou ao presidente dos ministros da Baviera um mapa no qual estavam indicadas as partes dos continentes ainda não ocupadas; imediatamente após, teve início a política colonial alemã.

Muito mais raras do que as falsas interpretações são as alucinações propriamente ditas. Somente em casos raros aparecem numerosas alucinações, especialmente do ouvido e do olfato, durante um prazo longo, com o decurso da moléstia; em regra só de vez em quando surge uma alucinação do ouvido, em geral, uma única palavra ou uma frase curta: "Henrique, Henrique! este bebe"; "Aî vem o pederasta profeta".

Pessoas na mesa próxima mexem as cabeças e murmuram observações que o doente claramente entende, pois que ele "teve um apurado ouvido". Ou durante o passeio é dado um tiro e o doente ouve o zumbido da bala que passa ao lado de sua cabeça, chega a sentir até a pressão do ar. Do ar cai uma delicada chuva de venenos sobre ele; uma repentina opressão ataca-o, e nesse momento ouve uma voz que o previne. São visões noturnas também que aparecem, vendo as estrelas, figuras luminosas, fenômenos divinos.

Uma promessa ressoa; ao doente é concedida a bênção de Esaú no ombro esquerdo e a de Jacó no ombro direito. Sempre costuma tratar somente de acontecimentos dispersos, que são considerados pelo doente como muito especiais, como excedendo o limite das coisas comuns.

$\mathrm{Na}$ formação da representação delirante, de per si, representam como me parece frequentemente um importante papel os erros de interpretação ou as falsas recordações.

Muitos dos fenômenos aparentemente alucinatórios têm na realidade sua origem. Passando o doente em revista os acontecimentos do seu passado caem-lhe "como escamas da vista". 
Com completa clareza vêm a seu encontro uma quantidade de particularidades que outrora absolutamente não tinha atendido, que agora, porém, repentinamente alcançam para ele alta significação.

Sua memória torna-se, como ele supõe, extraordinariamente afiada, de modo que toda sua vida passada se faz diante dele como um livro aberto.

O paciente sabe perfeitamente quando foi roubado, ainda pequeno de colo, de seus verdadeiros pais, carregado para ser abrigado junto de seus falsos pais. Frequentes ações e maneiras de externar-se destes últimos, o corte e a cor do traje, o tratamento na escola, sonhos proféticos, todos os grandes e pequenos acontecimentos do decurso de sua vida indicaram, desde sua tenra mocidade, sua ascendência e sua futura elevada posição. Um doente pouco instruído descreve a vila de seu pai que fora ministro das finanças em Hanover e se havia oposto aos planos de Windshorst. Quando lhe provaram nunca ter havido um ministro com seu nome, asseverava ele que, por inimizade, se havia aniquilado, falsificado e imprimido de novo todos os velhos manuais de estado de Hanover para abolir o nome de seu pai. Às vezes podemos seguir como tais reminiscências costumam aparecer no doente e fixar-se.

Um doente disse que outrora já tinham tomado como verdadeiro tudo o que ele conjecturava. A singularidade comum a todas as formações de delírio, originado pelos caminhos mais diversos, é a sua fundamental inabalabilidade que deveria repousar de um lado sobre a acentuação do senso e de outro sobre uma certa fraqueza de julgamento do paciente. Se eles concordam talvez que raras vezes ou nunca podem trazer a prova cabal da veracidade de suas apreciações, qualquer tentativa para persuadi-los da ilusão de suas ideias ricocheta como em uma parede, isto é, logo é rejeitada.

Age-se com tanta esperteza que o reconhecimento da ligação íntima de todas as aparentes causalidades só se deixa alcançar debaixo do ponto de vista subjetivo da convicção "que uma vez existia e existirá inabalável”, como dizia um doente.

"Eu vivo na persuasão que isso não é imaginário". O doente sente por isso, também, às vezes, que uma pessoa alheia não pode seguir totalmente o caminho de suas ideias e teme então que seus perseguidores possam utilizar-se desse estado de coisas para explicá-lo como um indivíduo atacado de delírio de perseguição.

De um reconhecimento da moléstia jamais fala; um doente dizia ser verdade que se achava atacado das faculdades mentais, pois que: "enquanto um homem sabe-se afastado de seu santo Deus existente, seu criador e conservador, por pecado ou culpa de seu próprio espírito mau, que vive de comer e beber; e como ele, paciente, não se conhece unido com Deus no espírito; e como na sua cons- 
ciência não se sente ainda defendido pelo Espírito Santo, é, então, compreensível por si só que ele carece e deve estar atacado das faculdades mentais".

Isso não é naturalmente um reconhecimento da moléstia, porém uma interpretação mórbida de noção, através da qual é conhecida a pretensão de uma crença rigorosa de sua relação com Deus.

Não raramente existe toda a espécie de queixas hipocondríacas sobre nervosismos, pressão na cabeça, debilidade de digestão, para os quais facilmente é tomado como causa o tratamento médico. Os doentes, pois, inventam várias espécies de caras para seus males.

O humor do doente fica preso sempre às mais íntimas ideias delirantes.

Sente as supostas perseguições como uma espécie de "tortura espiritual"; sente-se continuamente irrequieto e torturado; torna-se desconfiado, tímido, irritado. Por outro lado são os doentes contentes de si mesmos, pretensiosos, imperiosos, contestadores.

Frequentemente mudam de humor por causa das ideias delirantes.

Um doente em geral muito arrogante encontrei certo dia muito tímido, medroso, tremendo com todo o corpo, pois tinha ele concluído de uma palavra injuriosa que casualmente ouvira, que se o acusava de um assassinato há muito cometido. Às vezes aparecem também ideias de suicídio.

O medo de agir e o comportamento dos doentes podem ficar um tempo relativamente longo sem distintas perturbações. É verdade que seus modos de viver totais se apresentam com frequência irregulares e incompreensíveis. Um negociante, que na América tinha adquirido uma pequena fortuna e voltado de lá doente, foi consumindo pouco a pouco seu pecúlio, até viver da caridade pública, apresentando um orgulho demasiado, porque não queria aceitar um trabalho que estivesse em desacordo com o valor de sua pessoa. Somente, então, se externou que ele sofria havia 29 anos de franco delírio de perseguição com ideias de grandeza.

Apesar de boa aptidão, o doente não consegue nada fazer com perfeição, sendo em tudo malsucedido.

Como ele supõe em toda parte alianças secretas, em parte alguma se conserva por muito tempo, retrai-se, ocasiona cenas acidentais com seus amigos e parentes, que a estes ficam de todo incompreendidas.

Muitos desses doentes estão em condições de duradouramente de tal forma trancar em si suas lutas e desejos, que não são facilmente reconhecidos seus atos mórbidos no tráfego comum da vida diária. Não obstante aparece de vez em quando uma declaração enigmática, uma ação incompreensível, que atraem a atenção: curiosos costumes de vida, traje pouco comum, fanáticas predileções para certas tendências parciais e científicas populares, religiosas ou artísticas; muitas ve- 
zes os circunstantes costumam atribuir todas essas singularidades a uma personalidade fortemente desenvolvida ou a simples erros de caráter, sem penetrarem na sua profunda significação.

Para esquivar-se das perseguições contínuas e extorsões, o doente muda repentinamente sua colocação, baseado em pretextos sem importância, ou então começa a viajar. Não raramente esse meio serve para algum tempo, porém, muito em breve percebe ele que se encontra como uma pessoa já anunciada, estando-se totalmente a par de sua vida ulterior. Em toda espécie de alucinações tecem-se fios secretos dos que o cercavam outrora e nos quais agora o enlaçam. Em toda parte exercem espionagem sobre ele: algumas pessoas que ele, apesar do traje suposto disfarçado, barbas falsas, cabelos tintos, em toda a parte reconhece, seguem-lhe as pegadas, continuamente o vigiam de forma que sua posição frequentemente é pior "que um indivíduo perseguido por mandado de prisão". A sua percepção das dimensões e dos meios possantes do bando que o persegue estende-se nisso perenemente. Ao mesmo tempo toma-se sua aptidão para duradouras ocupações objetivas, para a execução regular de determinadas obrigações profissionais, sensivelmente influenciada pela constante inquietude de seu espírito; às vezes seu trabalho psíquico de per si não deixa reconhecer as perturbações mais grosseiras.

Debaixo do sentimento de crescente incerteza procura ele talvez estigmatizar publicamente, em forma de anúncios de jornais ou circulares, o indigno jogo de seus adversários, para defender-se das ocultas acusações.

Ele também levanta queixa por crime de injúria, pede o auxílio das autoridades, do chefe de Estado. Ou faz uso da defesa pessoal, esbofeteia um suposto espião no restaurante, procura dar um tiro num injuriador, atrair a atenção pública sobre sua pessoa e sua posição perigosa, por alguma ação que caia na vista.

Também aparece o suicídio.

As ideias de grandeza podem levar o doente a aproximar-se de seus supostos elevados pais, da sua augusta noiva, a princípio talvez por toda espécie de caminhos indiretos, passando diante da casa, deixando cair diante de estranhos notificações cheias de segredos as quais, ele está convencido, são bem compreendidas e levadas ao endereço determinado.

Ele escreve uma carta e como a mesma fica sem sucesso, uma segunda e terceira são enviadas; faz finalmente a tentativa de avançar pessoalmente às pessoas e autoridades envolvidas no seu sistema delirante. Quando o delírio de grandeza tem coloração religiosa, o doente aparece publicamente como apóstolo, procura formar uma comuna, introduzir um culto de Deus, [em] especial prega com palavras e por escrito, interrompe o sacerdote na igreja.

Frequentemente atos singulares ou perigosos, das mais diversas espécies, levam à internação do paciente em um hospício de alienados. Esse acontecimen- 
to é, para ele, um novo ato pérfido de seus rivais que já há muito lhe deram a entender que ele necessitava terminar pela loucura.

A princípio ele se adapta, pois que está certo que em breve se reconhecerá a sua boa saúde mental. Em seu modo de externar-se é muito retraído, desviase de perguntas penetrantes e oculta frequentemente durante muito tempo o ninho de suas ideias delirantes atrás de um comportamento exteriormente irrepreensível, até que uma coisa especial, uma excitação o descobre. Pouco a pouco reconhece que sua perseguição continua no hospício. Os médicos foram comprados para fazê-lo doente das faculdades mentais, pois que de outra forma não se conseguiu torná-lo acessível às maquinações. Pequenas brigas e inconvenientes, variações no estado, observações mostram-lhe que os ataques e intimidações também são colocados em campo pelo novo meio. Os outros enfermos do hospício absolutamente não são doentes, porém simuladores corrompidos, espiões da polícia cujo fim é examiná-lo por meio de seus atos absurdos. Ele exige, pois, muito vigorosamente a sua liberdade, escreve carta sobre carta por torná-la realizada, faz reclamações por causa da privação ilegal da liberdade, cria tentativas de evasão e conduz uma luta árdua pelos seus direitos humanitários, não raramente com grande habilidade e extrema perseverança. Então o doente reconhece que a permanência no hospício representa um anel da cadeia das provações a que ele precisa submeter-se para por fim alcançar o seu elevado alvo. Refletindo mais profundamente, ele conclui com clareza que já no seu passado estavam contidas frequentes indicações desse purgatório do hospício de alienados.

Muito distante, pois, de desânimo e desespero, ele deduz novas esperanças sobre o alcance também dos seus últimos e mais elevados destinos, da pontual realização de tudo aquilo que a sorte ulteriormente lhe havia destinado. Não raramente encontra essa sua apreciação uma especial confirmação na percepção, por ele em breve feita, de que também no hospício não estão ausentes indicações cheias de segredos sobre seu luzente futuro. Ele é tratado com especial atenção; deitam-lhe óleo de rosa em sua água de banho; dizem-lhe lisonjas com palavras encobertas; fazem-lhe chegar às mãos jornais e livros cujos conteúdos referem-se a ele. Não lhe pode, pois, passar despercebido que os médicos o retém somente "à ordem superior" e nem cogitam considerá-lo realmente doente. Entre estes doentes do hospício descobre ele pessoas altamente colocadas, que debaixo de nomes falsos foram postos conjuntamente com ele para the fazerem companhia.

O decurso da moléstia é em regra muito lento, quase sempre estacionário durante muitos anos. Os doentes ficam calmos, refletidos, conservam constantemente uma posição exteriormente em ordem, e até conseguem frequentemente ocuparem-se bem com trabalhos intelectuais. Um simples filho de camponês, que 
se considerava, numa só pessoa como imperador, papa, mais tarde até como imortal, debaixo das minhas vistas e com auxílios extremamente insuficientes, no decurso de alguns anos, aprendeu a ler regularmente nada menos de oito línguas vivas e mortas para alcançar a instrução necessária à sua elevada missão. Outros trabalham como artistas ou escritores, até com sucesso, ou então eles conseguem ao menos ganhar a sua vida; são somente considerados como homens originais, pois que trancam cuidadosamente em si suas concepções delirantes. Frequentemente eles levam na verdade uma vida inconstante, aventurosa, inconcebível, cheia de singularidades. Somente no decurso de algumas dezenas de anos, costuma fazer valer uma debilidade física crescente, diminuição da atividade espiritual debaixo do sucessivo progresso do sistema delirante. Quaisquer perturbações corporais, especialmente oscilação de peso, não são produzidas pela afecção mental, podem ser o resultado de circunstâncias casuais ou secundárias. A frequência da forma de loucura aqui descrita, segundo as minhas experiências, de longe não atinge a $1 \%$ dos recolhidos nos hospícios, provavelmente porque a maior parte dos doentes não carece de recolhimento no hospício ou só estão aí temporariamente.

A moléstia parece ser mais frequente nos homens do que nas mulheres.

Tendência hereditária à perturbação mental deveria representar saliente papel. Quanto ao resto são indicadas como causas sortes avessas da vida, desilusões, a luta com privações e necessidades; frequentemente devem elas ser consideradas mais como consequência do comportamento inadequado do doente, já há alguns anos.

No maior número dos casos, a moléstia apresenta-se entre os 25 e 40 anos. É verdade que Sander debaixo do nome de paranoia originária descreveu uma forma na qual, segundo a sua apreciação, a doença deveria ser traçada na juventude. Na verdade, ouve-se falar não raramente de tais como de outros doentes presos nas criações delirantes, que desde a mais tenra juventude estavam cheios de cismas e perseguições, que alegavam sua alta estirpe e poderosos inimigos. Eu, pouco a pouco, porém, pude certificar-me que nesses casos, quando muito, o começo da moléstia deixa verificar-se até a primeira metade do trigésimo ano.

Todas as outras narrações dos doentes, que alcançam o passado ulterior, são invenções posteriores.

Neisser indicou como sinal de reconhecimento do grupo citado por Sander, no qual são na realidade especialmente frequentes sinais de moléstia, de adulteração da recordação, e propôs a criação de uma "paranoia confabulante".

Não me parecer porém possível limitar sob esse ponto de vista um grupo unitário de outras formas. No maior número dos casos, trata-se além disso nos casos "originais" de uma hebefrenia rapidamente demencial. 
O reconhecimento da moléstia quase não oferece dificuldade, na observação atenta do lento desenvolvimento, das curiosas criações delirantes coordenadas, da excelente conservação da compreensão, assim como a ordem do curso das ideias, comportamento e ação. É verdade que, de passagem, uma série de moléstias de espécies totalmente diversas pode apresentar um quadro semelhante. A esta pertencem, antes de tudo, as formas da formação delirante da demência precoce. Como já anteriormente indiquei, eu quisera, para limitar, chamar especial atenção para a falta no nosso doente de uma própria perturbação da vontade. $\mathrm{Na}$ demência precoce encontramos sempre essa perturbação fundamental nas mais variadas formas, no negativismo, estupor, na estereotipia e excitação (Manierertheit), no automatismo das ordens e impulsividade. De todos esses traços não existe aqui nenhum vestígio. Ao contrário, os doentes portam-se duradouramente com completa naturalidade; todo o seu comportamento é pelas suas ideias delirantes completamente compreensíveis e em parte alguma mostra aquela perturbação e transplantação da relação entre a percepção, pensamento, senso e ação, que torna tão curioso o quadro da demência precoce. Especialmente faltam também estupor e inclinações ao estado de excitação (Erregungzustände); eu ao menos não estou em dúvida de que casos com tais fenômenos não pertencem à paranoia no sentido aqui circunscrito. Além disso, creio não me iludir supondo que com a falta da perturbação própria da vontade na paranoia, está na mais íntima relação com manifestações hipocondríacas (körperlichen Beeinflussungswahnes).

A percepção de que forças estranhas intervêm pelo caminho da telepatia na agitação do próprio corpo, sensações, ideias e ação de vontade é, como me parece, justamente nada mais do que precisamente a expressão da perturbação da vontade, que se torna reconhecível também no modo externo de portar-se do doente com demência precoce. Na legítima paranoia encontrei o delírio, talvez influenciado por veneno nos alimentos, jamais, porém, houve a percepção de ser o joguete escravo de diretas influências de outrem.

As ideias prejudiciais podem ser extremamente aventurosas e improváveis, elas se conservam, entretanto, como os delírios de grandeza, sempre no perímetro de processos naturais e possíveis, de vez em quando visionários. A própria personalidade corporal e física bem pode sofrer ou crescer, ser assunto do ódio ao portador de alta dignidade, porém ela conserva-se nas suas maneiras internas como era. O doente só é alienado sobre o papel que representa pelas ciladas inimigas, assim como pelas promessas e pretensões, porém ele mesmo não sucumbe a variação alguma, como tão frequentemente na demência precoce. A doença, pois, aqui, não destrói ou modifica o cunho da personalidade, porém ela só produz uma apreciação do mundo doentia e errada. A isso provavelmente deve estar ligado que 
as representações delirantes são mais ou menos perfeitamente fundamentadas, espiritualmente mais operadas e que argumentos são desmentidos com perspicácia e até talvez por sofismas.

A partir de suas suposições delirantes, forma-se no doente uma representação conexa dos acontecimentos, liga as suas observações baseadas em reflexão e segundo plano determinado. Ele está, pois, em condições de agir logicamente, de defender-se com tenacidade e até certo grau de perseguir seus alvos apaixonadamente e sem respeito.

Especialmente sente ele como pesada injustiça o roubo da liberdade, [de] outros direitos inerentes à maioridade, e não se cansa de combater, com todos os meios, contra isso. Em oposição isso, encontramos na demência precoce confusões de pensamento, depressões ou irritação sem sentido, confusão e impulsão da ação à perda da atividade do espírito e força de ação. Que nessa moléstia também as alucinações (Sinnestäuchugen) bastante mais fortes são aqui mencionadas de passagem.

Para os casos nos quais temos a tratar como simples delírio residual, só são válidos, em parte, os limites feitos a esses casos pelo que ficou dito. Aí podem faltar aos doentes, completamente, os indícios de uma perturbação da vontade, se até eles tinham sido existentes no auge da moléstia. Para isso, porém, nesses doentes que se comportam com naturalidade e se ocupam, apegando-se também às suas concepções delirantes, sentimos falta de qualquer continuação no desenvolvimento destas últimas. Os acontecimentos delirantes jazem atrás deles, não continuam a tecer-se na atualidade e não influenciam na ação futura. Também as aparições delirantes dos epilépticos, indevidamente às vezes observadas, têm os traços de um delírio residual, que perdeu o seu valor para o atual estado dos doentes.

No auge do seu desenvolvimento deve, ao lado dos sinais da epilepsia, pelo seu modo agudo de aparecimento e predomínio das alucinações, a diferenciação da paranoia ser feita mais tarde, e é fixada pelo desaparecimento do delírio, dado o mau humor irritável que acompanha a epilepsia. Análogo argumento vale para as psicoses dos bebedores, cujo posterior desenvolvimento na maior parte depende da ação do álcool; elas param ou voltam atrás, logo que é vedada ao doente a possibilidade de beber, enquanto o delírio dos paranoicos, pela colocação no hospício, somente encontra novo alimento. Nas graves formas de delírio dos bebedores é verdade que frequentemente também se apresentam alucinações que conduzem à representação de ligações telepáticas. Mas os doentes são fracos de vontade e pouco inclinados ao trabalho próprio. Finalmente, os casos de loucura maníaco-depressiva, que pelas suas alargadas formações delirantes lembram a paranoia, com a observação mais nítida sempre se deixam reconhecer pela indi- 
cação das perturbações que nós dantes discutimos, nitidamente como sinais básicos daquela moléstia. ${ }^{4}$

\section{Resumos}

(Paranoia [Verrücktheit] - 1904)

This is the Brazilian translation (1905) of the chapter on paranoia, in seventh German edition (1904) of Emil Kraepelin's Textbook (Lehrbuch). In it he discusses the diagnosis of paranoia and, especially, makes a distinction between it and dementia praecox.

Key words: Emil Kraepelin, history of paranoia , history of dementia praecox

(Paranoïa [Verrücktheit] - 1904)

Ce qui suit est la traduction brésilienne (1905) du chapitre sur la paranö̈a, extrait de la septième édition allemande (1904), du traité (Lehrbuch) de psychiatrie d'Emil Kraepelin. L'auteur discute le diagnostic de la paranoïa et, en particulier, la distinction entre la paranoïa et la démence précoce.

Mots clés: Emil Kraepelin, paranoïa - histoire, démence précoce - histoire

(Paranoia [Verrücktheit] - 1904)

Aquí publicamos la traducción brasileña (1905) del capítulo relativo a la paranoia, extraído de la séptima edición alemana (1904) del tratado (Lehrbuch) de psiquiatría de Emil Kraepelin. El autor discute el diagnóstico de paranoia y, en particular, distingue entre la paranoia y la demencia precoz.

Palabras clave: Emil Kraepelin, paranoia - historia, demencia precoz - historia

\section{Emil KraePelin (1856-1926)}

Médico alemão, foi professor de psiquiatria em Heidelberg (1891-1903) e em Munique (1904-1922). Seu importante Lehrbuch de psiquiatria teve nove edições, entre 1883 e 1927, e circulou amplamente nos meios psiquiátricos internacionais, inclusive no Brasil. Kraepelin considera o padrão clínico, o curso e o desfecho das enfermidades mentais como sendo os principais critérios de delimitação nosológica. A demência precoce (depois chamada de esquizofrenia), a psicose maníaco-depressiva e a paranoia são algumas das mais significativas entidades descritas em suas classificações.

4. Estes delírios coordenados que aparecem na psicose epiléptica, na psicose alcoólica e na loucura maníaco-depressiva são chamados erroneamente pelos autores paranoia epiléptica, alcoólica e periódica. (N. da T.) 